\title{
Drought analysis and management for Tamil Nadu: Science-stakeholder-policy linkage
}

\section{R. GOWTHAM*, V. GEETHALAKSHMI, N. KUMAR, A. LAKSHMANAN, K. BHUVANESWARI, GA. DHEEBAKARAN and K. SENTHILRAJA}

\author{
Tamil Nadu Agricultural University, Coimbatore, Tamil Nadu - 641 003, India
}

*Corresponding Author: gowtham.acrc@gmail.com

\begin{abstract}
The complex and multi-dimensional nature of droughts in Tamil Nadu state and its impact on agricultural sector and farming community requires a thorough analysis for developing short and longterm adaptation and mitigation measures with institutional arrangement and policy support. In the present investigation, drought analysis was made for Tamil Nadu state using 148 years (1871 - 2018) monthly rainfall data obtained at district scale from India Meteorological Department (IMD) and Tamil Nadu Agricultural University by employing various drought indices. Larger co-efficient of variation (139 and 149 $\%$ ) during the major growing seasons (Southwest and Northeast monsoon)evidenced high undependability of rainfall over Tamil Nadu. Drought Index (DI) analysis indicated a 51 per cent drought years in SWM and 48 per cent in NEM season, while Standardized Precipitation Index (SPI) exhibited 43 and 48 per cent of drought years in SWM and NEM respectively, indicating occurrence of drought once in every four years. More number of Consecutive Drought years (CDY) posed serious impacts on food production and livelihoods. Drought management framework as well as input for designing drought policy for Tamil Nadu.
\end{abstract}

Key words: Drought, Tamil Nadu, stake holders, policy

In India, dryland agriculture is occupying almost 60 per cent of the net sown area (NRAA, 2012), contributing to 44 per cent of the total food grains production (Singh et al., 2004). In the recent times, due to erratic monsoon rainfall, the frequency of drought and floods are increasing leading to decline in agriculture sector Gross Domestic Product (GDP) from 46 per cent (1960) to 15.4 per cent in 2017.During drought years like 2012, GDP was only13.9 per cent (CSO, 2019). Chetan Chauhan (2017) reported that 40 per cent of the districts in India are drought prone. Tamil Nadu State, with around 45 per cent of the total cultivable area under dryland agriculture, is prone to frequent droughts, that are triggered by monsoon failures and has affected water storage in all the water bodies (Nathan, 2001). The drought in 2002 was unprecedented in its severity affected 21 out of 32 districts in Tamil Nadu with a rainfall deficiency ranging from 21 to 52 per cent (Department of Agriculture, 2006). The Government of Tamil Nadu had incurred an expenditure of Rc 3736 million for drought management during $10^{\text {th }}$ plan period, of which Rc 2687 million was spent for 2002 - ' 03 drought alone (Directorate of Economics and Statistics, 2003). Between 2011 and 2014, the food price inflation in the Tamil Nadu State increased from 7.4 to 12 per cent, mainly due to vagaries of monsoon (Economic survey,
2017). Almost 90 per cent of the surface water potential and 80 per cent of ground water potential has already been exploited (ENVIS, 2020). The negative shift in rainfall affects the economy and food security of the State and the most vulnerable are small and marginal farmers. This necessitates a need for developing appropriate drought policy and in this paper, the drought frequency and intensity over Tamil Nadu was assessed using the long-term rainfall data and with strong stakeholder integration, attempts were made to identify the challenges in management of drought and to develop a framework for comprehensive drought policy for Tamil Nadu State.

\section{MATERIALS AND METHODS}

The study was conducted as two parts. The first part is scientific assessment of drought using drought indices. The second part is stakeholder's integration for field level assessment of drought impact, identification of challenges in drought management and development of drought policy framework for Tamil Nadu state.

\section{Study area}

Entire state of Tamil Nadu was considered for the drought analysis. Tamil Nadu is one of the most water scarce 
States in India, dependent on both southwest monsoon (Jun - Sep) and the northeast - the life line monsoon (Oct- Dec) seasonal rains. The spatial variation in annual rainfall for Tamil Nadu is presented in Fig. 1. Normal rainfall with rainfed cropping system practiced in different districts, obtained as per the 2019 records of Department of Economics and Statistics, Government of Tamil Nadu (Table 1). The average farm size in the state is $0.83 \mathrm{ha}$ and 91 per cent of the farmers belonging to small and marginal category, highly vulnerable to any changes.

\section{Part 1: Drought analysis over Tamil Nadu}

Monthly rainfall data for Tamil Nadu was collected for a period of 148 years from 1871 to 2018 from India Meteorological Department (IMD) and Tamil Nadu Agricultural University. The coefficient of variation forannual and seasonal rainfall of Tamil Nadu was calculated to understand the dependability of rainfall. The drought frequency and intensity over the past 148 years were analysed using following drought indices

Drought index (DI) : Drought index is calculated by taking the difference between actual precipitation $(\mathrm{P})$ and long term mean precipitation $(\mathrm{X})$ and dividing it by Standard Deviation (SD) i.e, DI = (P-X) / SD (Hayes et al., 2003). The $\mathrm{DI}$ is classified into four categories viz., light drought (DI $=<$ $-0.1)$, moderate drought $(\mathrm{DI}=<-0.2)$, severe drought $(\mathrm{DI}=$ $<-0.5)$ and very severe drought $(\mathrm{DI}=<-0.8)$.

Percent of normal (PN) : Percent of normal is one of the simplest drought monitoring tools which is expressed as the actual rainfall in percentage compared to the normal rainfall (Tadesse et al., 2004; Morid et al., 2006). The values of PN has been modified according the local conditions and classified as Verywet (PN $>150 \%$ of normal rainfall (NR)), Moderately wet (PN $>130 \%$ to d" $150 \%$ of NR), Near normal (PN $>90 \%$ to d" $130 \%$ of NR), Moderate drought(PN $>70 \%$ to d" $90 \%$ of NR), Severe drought (PN $>40 \%$ to d" $70 \%$ of NR) and Extreme drought (PN 40\% d" of NR).

Standardized precipitation index (SPI) : The SPI was designed by transforming the probability of observed into an index (McKee et al., 1993) to quantify the precipitation deficit for multiple time scales. $\mathrm{SPI}=\left(\mathrm{X}_{\mathrm{ik}}-\mathrm{X}_{\mathrm{i}}\right) / \tilde{\mathrm{A}}_{\mathrm{i} \text {; Where }}, \tilde{\mathrm{A}}_{\mathrm{i}}=$ Standardized deviation for the $\mathrm{i}^{\text {th }}$ station; $\mathrm{Xik}=$ Precipitation for the $\mathrm{i}^{\text {th }}$ station and kth observation; $\mathrm{X}_{\mathrm{i}}=$ mean precipitation for the $\mathrm{i}^{\text {th }}$ station. For calculating SPI, 30 years or more of continuous monthly precipitation data is needed. Positive SPI values indicate greater than median precipitation and Negative SPI values indicate less than median precipitation.
Based on the SPI values, conditions are classified as Extremelywet (SPI $>2.0$ ), Very wet (1.50 to 1.99), Moderately wet (1.00 to 1.49), Mildly wet ( 0 to 0.99 ), Mild drought (0 to -0.99), Moderate drought (-1 to -1.49), Severe drought (-1.50 to -1.99) and Extreme drought (Less than -2.00).

Consecutive Drought : Consecutive drought years were calculated if the Drought Index (DI) values are $<-0.5$ in the consecutive years.

\section{Part 2: Stakeholder's integration for development of drought management framework}

Impact of serious droughts with varying intensity over the last four decades on agriculture and food production was gathered from the Department of Agriculture and from Department of Economics and Statistics records and discussed with the stakeholders. During September 2019, a stakeholders meeting was conducted to develop a drought management framework under DST- SPLICE division sponsored project entitled "Building Resilience to Climate Change and Improving Food Security through Climate Smart Solutions (BRIFS)". Various stakeholders including the officials from Agriculture Depart of Government of Tamil $\mathrm{Nadu}$, representatives from Water Resources Organization, NGOs, farmer representatives, extension functionaries and scientists from Tamil Nadu Agricultural University (TNAU) interacted to develop Drought Management Framework based on their past interventions, experiences and future needs.

\section{RESULTS AND DISCUSSION}

\section{Part 1: Drought analysis over Tamil Nadu}

The average annual rainfall of the State is $945 \mathrm{~mm}$, of which 48 per cent is received from thenortheast monsoon (NEM) and 32 per centfrom thesouthwest monsoon (SWM) and the details are presented in Fig.2. The peak rainfall months are October and November (Fig.3).Rainfall plays major role in influencing theoccurrence and intensity of drought. The coefficient of variation of winter,summer, SWM, NEM and the annual rainfall of Tamil Nadu are 49, 41, 72, 139 and 149, respectively, indicating that the rainfall received during the major growing seasons viz.,SWMand NEMare highly undependable.

The drought years, frequency and intensity of Tamil Nadu over the past 148 years (1871-2018)analysed using drought indices are presented in Table 2 and 3. Drought Index (DI) analysis demonstrated that the chance of occurrence of a meteorological drought in the State is 51 
Table 1 : Rainfall pattern and rainfed cropping systems in the districts of Tamil Nadu

\begin{tabular}{llll}
\hline Annual Rainfall & Districts & Area & Rainfed Cropping systems \\
\hline Below $800 \mathrm{~mm}$ & $\begin{array}{l}\text { Namakal, Erode, Coimbatore, } \\
\text { Tiruppur, Karur, Theni and } \\
\text { Thoothukudi }\end{array}$ & $25.0 \%$ & $\begin{array}{l}\text { Single crop during Northeast } \\
\text { monsoon : Maize / sorghum / } \\
\text { cotton / groundnut }\end{array}$ \\
& $\begin{array}{l}\text { Vellore, Dharmapuri, Krishnagiri, } \\
\text { Tiruchirapalli, Pudukottai, Madurai, } \\
\text { Dindugal, Ramananthapuram, } \\
\text { Virudhunagar, Sivagangai and }\end{array}$ & $36.8 \%$ & $\begin{array}{l}\text { Single crop during the Northeast } \\
\text { monsoon / two short duration crops } \\
\text { overlapping the SWM and } \\
\text { Nirunelveli }\end{array}$ \\
$\begin{array}{l}\text { Above 1,000mm seasons } \\
\text { Tiruvalluvar, Vilupuram, } \\
\text { Tiruvannamalai, Salem, Thanjavur, } \\
\text { Ariyalur, Peramblur, Tiruvarur, } \\
\text { Kanniyakumari, Chennai, Cudalur, } \\
\text { Kanchipuram, Nagapattinam and } \\
\text { The Nilgris }\end{array}$ & $37.9 \%$ & $\begin{array}{l}\text { Two crops during SWM and NEM } \\
\text { seasons: Mainly paddy based } \\
\text { cropping system(or) One single long } \\
\text { duration crop like sugarcane / } \\
\text { banana (or) plantation crops }\end{array}$ \\
\hline
\end{tabular}

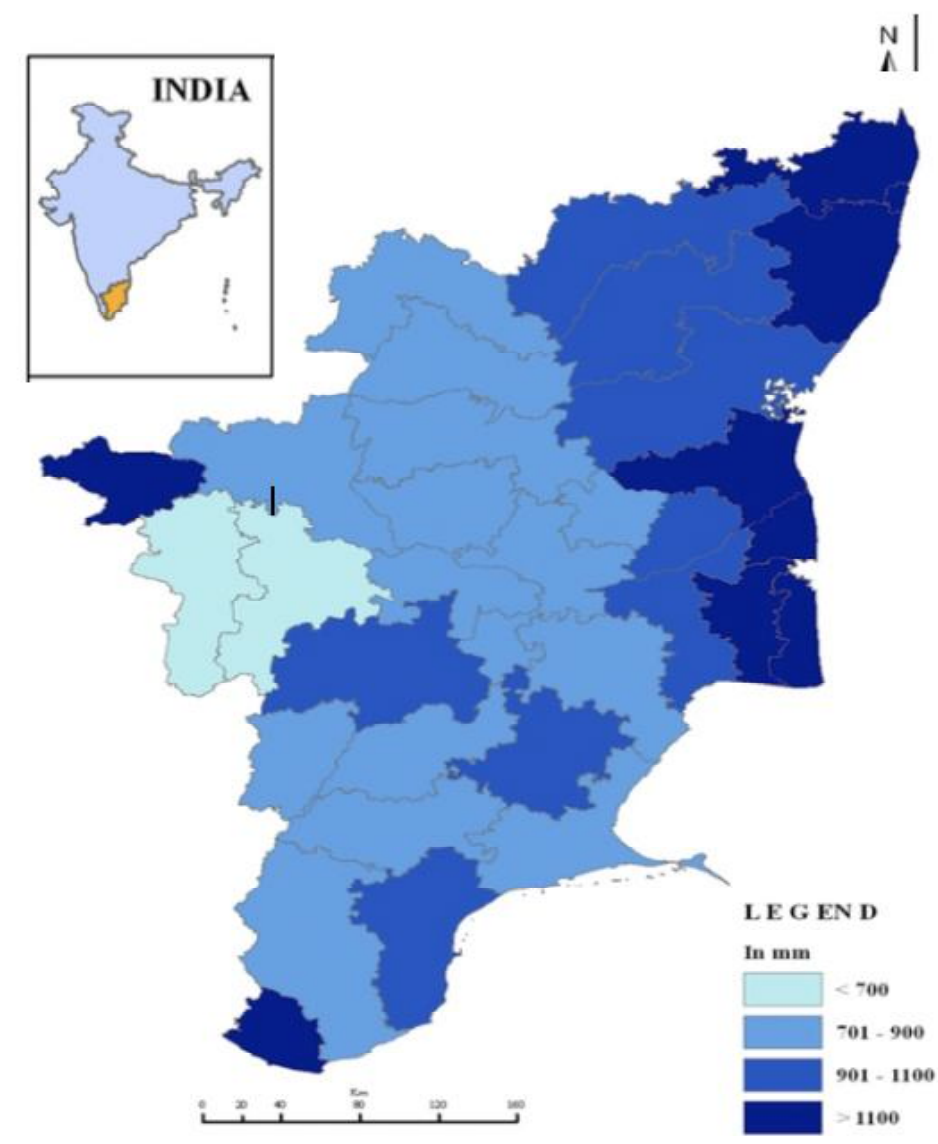

Fig.1:Spatial variation in Annual rainfall of Tamil Nadu

and 48 per cent during SWM and NEM seasons respectively. As per Percent of Normal (PN) index, only 23 per cent of the years in the SWM and 28 per cent of the years in the NEM experienced drought. According to SPI values, 43 per cent of the years in the SWM and 48 per cent of the years in the
NEM did experience drought, which means that once in four years, there was a drought in Tamil Nadu. Study on analysis of the frequency of7, 6,5,4,3 and 2 Consecutive Drought Years (CDY) occurred over Tamil Nadu for the past 148 years $(1871-2018)$ indicated that six consecutive years of 
Table 2:Drought years under the different drought indices

\begin{tabular}{llll}
\hline $\begin{array}{l}\text { All three criteria (DI, PN, } \\
\text { SPI) }(28 \% \text { of the years) }\end{array}$ & $\begin{array}{l}\text { Two criteria(DI, SPI) } \\
\text { (45\% ofthe years) }\end{array}$ & $\begin{array}{l}\text { Two criteria(PN, SPI) } \\
(28 \% \text { ofthe years })\end{array}$ & $\begin{array}{l}\text { SPIalone } \\
\text { (47\% oftheyears })\end{array}$ \\
\hline $1873,1875,1876,1878,1881$, & $1871,1873,1875,1876,1878,1879,1881$, & $1873,1875,1876,1878$, & $1871,1873,1875,1876,1878,1879$, \\
$1889,1892,1894,1897,1899$, & $1885,1889,1890,1892,1894,1897,1899$, & $1881,1889,1892,1894$, & $1881,1885,1889,1890,1891,1892$, \\
$1904,1905,1908,1911,1926$, & $1900,1904,1905,1907,1908,1911,1917$, & $1897,1899,1904,1905$, & $1894,1897,1899,1900,1904,1905$, \\
$1927,1934,1935,1938,1942$, & $1918,1926,1927,1928,1933,1934,1935$, & $1908,1911,1926,1927$, & $1907,1908,1911,1917,1918,1924$, \\
$1945,1948,1949,1950,1952$, & $1936,1938,1942,1945,1947,1948,1949$, & $1934,1935,1938,1942$, & $1926,1927,1928,1929,1933,1934$, \\
$1958,1968,1974,1980,1982$, & $1950,1951,1952,1957,1958,1959,1965$, & $1945,1948,1949,1950$, & $1935,1936,1938,1942,1945,1947$, \\
$1986,1988,1989,1994,1995$, & $1968,1969,1970,1973,1974,1975,1976$, & $1952,1958,1968,1974$, & $1948,1949,1950,1951,1952,1957$, \\
$1999,2003,2012,2013,2014$, & $1980,1982,1986,1987,1988,1989,1992$, & $1980,1982,1986,1988$, & $1958,1959,1965,1968,1969,1970$, \\
2016 & $1994,1995,1999,2001,2002,2003,2012$, & $1989,1994,1995,1999$, & $1973,1974,1975,1976,1980,1982$, \\
& $2013,2014,2016,2018$ & $2003,2012,2013,2014$, & $1986,1987,1988,1989,1992,1994$, \\
& & 2016 & $1995,1999,2001,2002,2003,2012$, \\
\hline
\end{tabular}

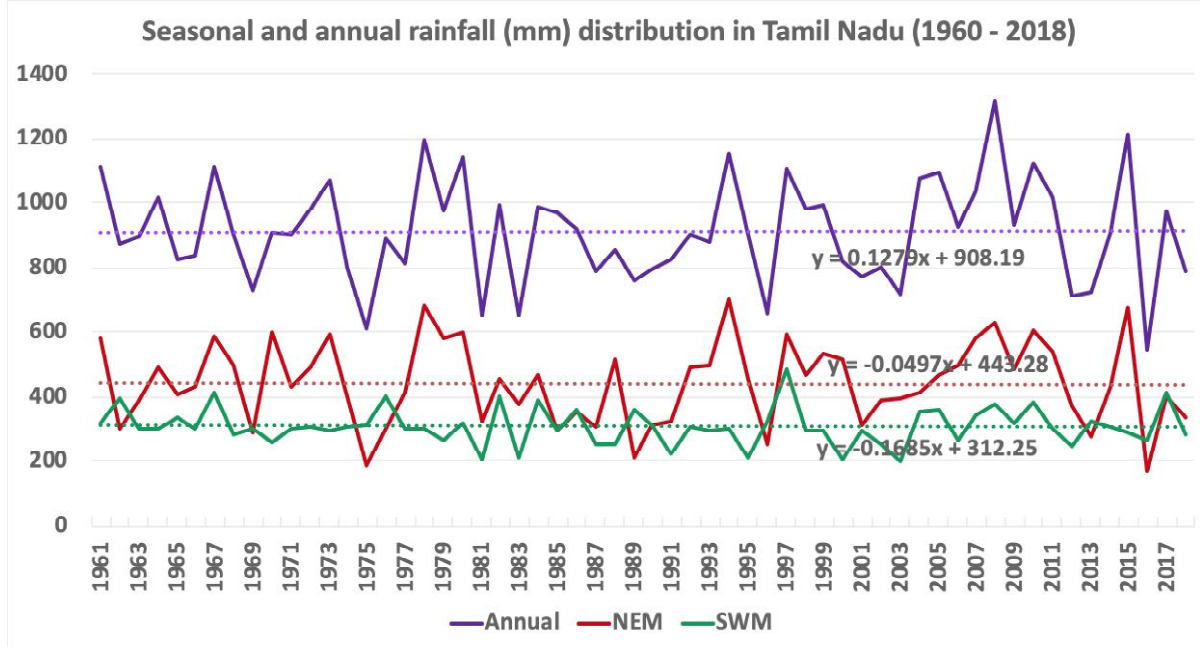

Fig.2: Annual, Southwest and Northeast monsoon rainfall of Tamil Nadu (1961-2018)

drought happened from 1947 to 1952 and five consecutive years of drought occurred from 1986 to 1990 . Similarly, 4, 3 and 2 consecutive drought years happened for 4, 3 and 7 times, respectively in the last 148 years (Table $4 a-4 d$ ). Consecutive drought for more than 3 yearmight lead to famine and serious impacts on food production and livelihoods.

\section{Part 2: Development of drought policy framework Impact of major droughts in Tamil Nadu}

Significant impacts in acute drought years over Tamil Nadu are listed below.

1980: Acute drinking water problem; groundnut crop cultivated in 100,000 ha got destroyed in Chengalput, Tiruvannamalai and Vellore Districts; Coconut and mango orchards dried up in large areas; Reduction in employment for agricultural labourers.

1982: 70 per cent reduction in area under paddy cultivation; declinein yield of paddy, millets groundnut and pulses in all the districts. Loss of 6000 ha of tea plantation in the Nilgiris District. Hydropower generation failures due to low water level in Mettur Dam.

1987, 1989: The ground water table reduced to more than $11 \mathrm{~m}$ below normal. Paddy was cultivated only in 20 lakh ha against the normal of 24 lakh ha. Production of paddy, millets and pulses dropped by 10, 4 and 1 lakh tons, respectively. Agricultural labourers migrated in search of employment.

2016: Worst drought in 140 years, all 32 districts in the state 
Table 3 : Drought frequency and intensity in Tamil Nadu

\begin{tabular}{|c|c|c|c|c|c|c|}
\hline Seasons & \multicolumn{3}{|c|}{ per cent of all drought years } & \multicolumn{3}{|c|}{ per cent of severe and very severe drought years } \\
\hline Southwest monsoon & 51 & 23 & 43 & 33 & 14 & 9 \\
\hline Northeast monsoon & 48 & 28 & 48 & 33 & 22 & 10 \\
\hline Annual & 48 & 27 & 47 & 34 & 3 & 5 \\
\hline
\end{tabular}

Note: DI: Drought Index; PN: Percent of Normal; SPI: Standardised Precipitation Index

Table 4a:Frequency of consecutive droughts detected through DI, PN and SPI in Tamil Nadu (1871 - 2018)

\begin{tabular}{llllll}
\hline Consecutivedrought & 6 years & 5 years & 4 years & 3 years & 2 years \\
\hline Frequency & - & - & - & 1 & 7 \\
\% of frequency & - & - & - & 12.5 & 87.5 \\
Years & - & - & - & $1948-1950$ & $1875-1876,1904-1905$, \\
& & & & & $1926-1927,1934-1935$, \\
& & & & $1988-1989,1994-1995$, \\
\hline
\end{tabular}

Table 4b:Frequency of consecutive droughts detected through DI and SPI in Tamil Nadu (1871-2018)

\begin{tabular}{llllll}
\hline Consecutive drought & 6 years & 5 years & 4 years & 3 years & 2 years \\
\hline Frequency & 1 & 1 & 6 & 3 & 5 \\
\% of frequency & 6.3 & 6.3 & 37.5 & 18.8 & 31.3 \\
Years & $1947-1952$ & $1986-1990$ & $1889-1892,1904-1908$, & $1926-1928$, & $1875-1876,1878-$ \\
& & & $1933-1936,1973-1976$, & $1957-1959$ & $1879,1899-1900$, \\
& & & $2001-2003,2012-2014$ & $1968-1970$ & $1917-1918$, \\
\end{tabular}

Table 4c:Frequency of consecutive droughts detected through PN and SPI in Tamil Nadu (1871-2018)

\begin{tabular}{|c|c|c|c|c|c|}
\hline Consecutive drought & 6 years & 5 years & 4 years & 3 years & 2 years \\
\hline Years & & & & $1948-1950,2012-2014$ & $\begin{array}{l}\text { 1875-1876,1904-1905, } \\
1926-1927,1934-1935, \\
1988-1989,1994-1995\end{array}$ \\
\hline
\end{tabular}

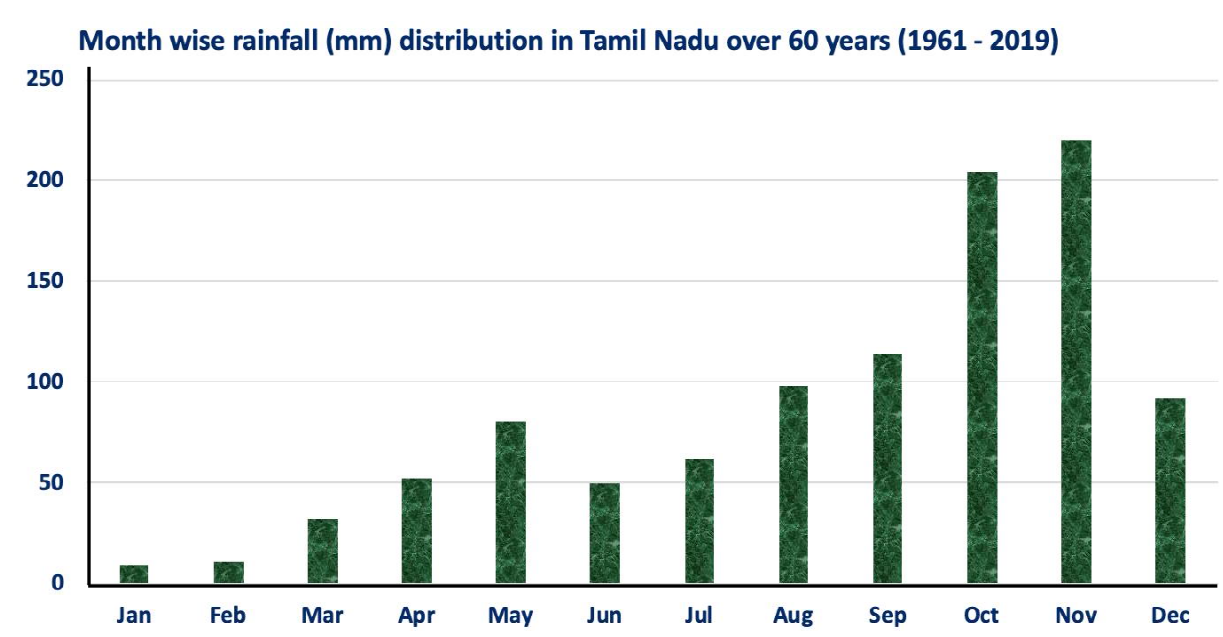

Fig.3: Monthly rainfall distribution in Tamil Nadu 
Table 4d:Frequency of consecutive droughts detected through SPI in Tamil Nadu (1871 - 2018)

\begin{tabular}{llllll}
\hline Consecutive drought & 7 years & 6 years & 4 years & 3 years & 2 years \\
\hline Frequency & 1 & 1 & 4 & 3 & 7 \\
\% of frequency & 6.3 & 6.3 & 25.0 & 18.8 & 43.8 \\
Years & $1986-1992$ & $1947-1952$, & $1889-1892$, & $1957-1959$, & $1875-1876,1878-1879$, \\
& & & $1926-1929$, & $2001-2003$, & $1904-1905,1907-1908$, \\
& & $1933-1936$, & $2012-2014$ & $1917-1918,1969-1970$, \\
\end{tabular}

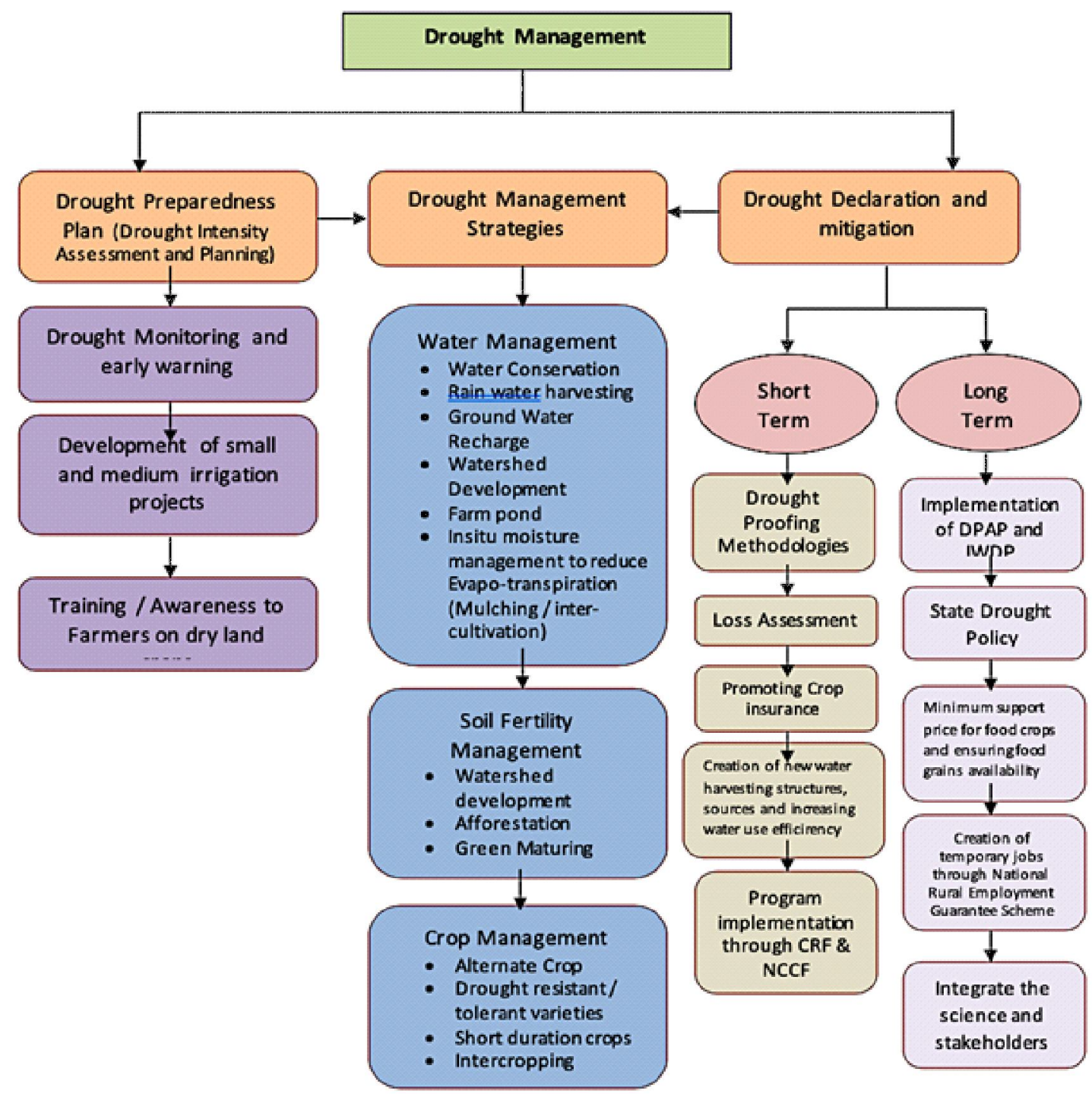

Fig.4: Drought Management Framework

had received rainfall which was "scanty or deficient and the range is from 35 per cent to 81 per cent," and the state had been declared drought-hit.

2018: About 24 of 32 districts had hit by hydrological drought of which 19 districts were reported a fall in groundwater levels in 2019, compared to 2018.
Consecutive drought occurred during 1986-1989; 1995-1997; 1995-1997; 2002 -2004; 2012 -2013,left catchment areas nearly dry and more than one million cattle got severely affected. Reduction in ground water level from two to 11 meters resulted in acute drinking water problem in many districts. The food grain production dipped to 44.61 
Table 5:Drought management challenges and suggested mitigative options

\begin{tabular}{|c|c|}
\hline Component & Challenges in drought management \\
\hline \multirow[t]{10}{*}{ Institutional } & a. Integration of stakeholders for defining \\
\hline & destinations, road maps and mile stones for \\
\hline & drought management. \\
\hline & b. Institutional participation (Government \\
\hline & Departments, Technology providing \\
\hline & Institutions, NGOs and Extension functionaries) \\
\hline & for pre and post impact governance \\
\hline & c. Evolving suitable drought management \\
\hline & policies to translate short-term relief measures \\
\hline & into long-term interventions of drought \\
\hline
\end{tabular}

Technological a. Setting up of centralized data base at State level for drought monitoring and assessment

b. Identification of standard procedure for drought declaration, drought vulnerability assessment and identification of drought prone areas

c. Identification of location specific best practices for better drought management and updating the disaster management plans
Suggested mitigative options

a. Strengthening State level Institutional set up viz., "Tamil Nadu Disaster Management Authority (TNDMS)"under Department of Environment, Government of Tamil Nadu, involving key stakeholders such as scientists, policy makers of various Government Departments including agriculture and PWD, District level administrators, NGOs, Community based organizations and farmer representatives, supported by adequate financial resources to monitor the drought onset, progress and its impact on various sectors.

b. Suitable short-term and long-term policies and financial support may be provided from the Government to implement and support drought management plan at various levels.

a. Creation of "Drought Monitoring and Early Warning Cell" under TNDMS involving representatives from India Meteorological Department, State Department of Agriculture, State Agricultural Universities and Water Resources Organization of Public Work Departments to create centralized data base, monitor and declare drought.

b. Application of advanced tools such as remote sensing technology and ICT in drought monitoring, forecasting/early warning, and communication to the last mile for drought mitigation.

c. Technology providers such as TNAU, could help in designing location specific contingency plans to manage the drought situation and build the capacity of various stakeholders in managing and mitigating the drought effects. lakh tonnes during 2002- 2003 against the targeted production of 93.35 lakh tonnes. Cauvery delta farmers in Tamil Nadu have lost both Kuruvai and Samba rice crop and a large number of agricultural labourers migrated to other neighbouring states for employment. During 2012-2013, drought was much severe to completely dry about 7000 Palmyra trees, which is very hardy to drought

\section{Drought management framework}

Drought Management Framework developed from the stakeholders' interactive meeting has three segments Viz., drought preparedness plan, drought declaration and mitigation and drought management strategies (Fig. 4). The challenges related to institutional arrangement and technological interventions and possible ways to address them are presented in Table 5. Drought preparedness plan including drought monitoring and early warning is done by IMD and the Department of Agriculture \& Cooperation (GOI). Tamil Nadu Agricultural University is providing district level probabilistic seasonal rainfall prediction based on ENSO and IOD for SWM and NEM seasons for making strategic agricultural decisions such as choice of crop, land configuration, varietal selection and crop management techniques (Geethalakshmi et al. 2017). With the help of dense network of Automatic Weather Stations established at block levels in the State, TNAU monitors the rainfall situation in Tamil Nadu. Additionally, crop and soil moisture conditions are assessed for helping the Department of Agriculture for 
INSTITUTIONAL LINKAGES FOR DROUGHT MANAGEMENT

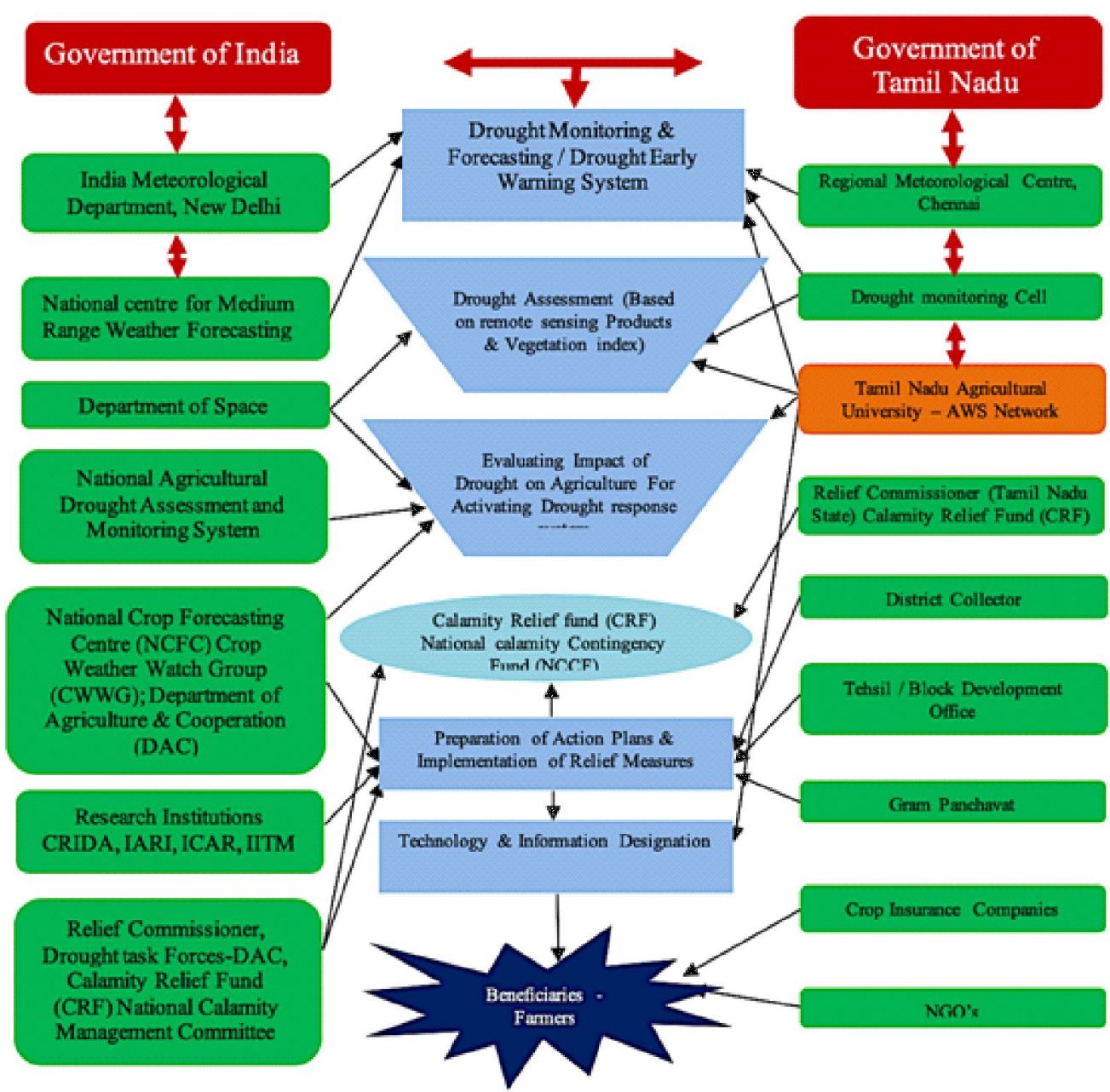

Fig.5: Key Stakeholders, Implementers and Agencies for Drought Management

planning drought declaration and relief measures.For managing the drought, different strategies (Fig.4) for water management, soil fertility management and crop management were identified.

\section{Institutional linkages for drought management}

Based on the discussions and suggestions from the stakeholders meeting, flow chart is proposed to link different institutions with specific roles in managing the drought in the State of Tamil Nadu (Fig. 5). The Government of India (GOI) provides policy and guidelines. The Department of Agriculture and Cooperation (DAC) in the Ministry of Agriculture is the central coordinating and advisory agency. The Central Relief Commissioner (CRC) at the Department is the focal point for interaction with State Government and Central agencies/Departments. NGOs are also involved in drought management.

\section{Initiatives and programmes by the Government of Tamil Nadu to mitigate drought}

Drought Prone Areas Programme (DPA) ofthe Tamil Nadu includes Watershed Development Agency (TAWDEVA), Integrated Wasteland Development Programme (IWDP), National Watershed Development Project for Rain fed Areas (NWDPRA), Watershed Development Fund (WDF) and Integrated Watershed Management Programme (IWMP). TAWDEVA is the Nodal Agency for various State / Central schemes such as National Agriculture Development Programme (NADP), National Food Security Mission (NFSM), Agriculture Technology Management Agency (ATMA), Agriculture Resource Information Systems and Networking (AGRISNET), National Project on Management of Soil Health \& Fertility and Western Ghats Development Programme (WGDP).In Tamil Nadu, 670,000 hectares is benefited from tank irrigation. Government has initiated 
tank modernization programme with support from European Economic Committee during 1984 and improved 649 tanks in Tamil Nadu (NRAA, 2012).

\section{Drought policy}

Based on the drought management framework and the institutional linkages specific recommendation that aresimple, dynamic and actionable in planning right interventions at different stages of drought evolutionwas identified and presented as suggested drought policy for Tamil Nadu state.

a. Broad spectrum recommendations : Agroclimatic zones of Tamil Nadu to be redefined to micro level and accordingly strategies to be evolved for making the state drought resilient. It is suggested to link the knowledge institutes, stakeholders, agencies and communities. Setting up of district level functional drought monitoring cell under the Department of Environment, Government of Tamil Nadu, involving relevant agencies and institutions. Financial support needs to be provided for strategically planning and implementing water conservation programmes. The social perspective of the drought in terms of drought severity on the basis of socioeconomic parameters should be mainstreamed. Policies for increasing the forest cover through agro forestry, social forestry and afforestation programmes to improve resilience or robustness should also be in place.Policies for conserving water through rainwater harvesting programme for erecting the structures like farm ponds in farmers field, community farm ponds, percolation ponds, and check dams in rainfed areas. In the tankfed areas, restoration of water bodies, desilting of tanks, ground water recharge structures and creation of micro irrigation facilities. Strengthening of banks, desilting of tanks and awareness programme for efficient usage of water in the canal irrigated areas.

b. Drought monitoring and prediction : Intensification of observational network for collection of meteorological data on real time basis and to ensure information flow is necessary.Drought information open database with past and real time weather information, historical drought events, their location specific impacts and mitigative action may be created for designing future action plans. Facilities need to be created for building the human capacity for improving the accuracy of drought prediction/early warning involving Regional Meteorological Centre, Chennai and Tamil Nadu Agricultural University.

c. Drought management and mitigation measures: Location specific drought management tool box to be developed with short term interventions and long-term planning. Drought preparedness including safety nets, Weather Based Crop Insurance (WBCIS), etc., should be factored into the normal farm management plans and activities. Enhancing water use efficiencies in conjunction with rainwater harvesting, rehabilitation of traditional water storage structures coupled with solar powered micro irrigation systems (drip and sprinkler) need to be promoted. Location specific cropping pattern to be evolved in harmony with crop water demand and supply linked with marketability at the same time suggesting better alternative crops against high water demanding crops. Creation of livelihood for agricultural labours by generating alternative employment and income source from allied agricultural activities such as goat rearing, dairy and value addition to agricultural products integrating with existing programs such as National Rural Employment Guarantee Programme (NREGP) is essential. Integrated farming systems approach involving social capital of humans, livestock and other subsidiary income generating activities need to be promoted.

d. Extension and Communication: The farming community should be sensitized on the recurrence of frequent droughts and the need for preand post drought management through eco-friendly resource utilization.Information delivery at right time using modern ICT tools, Village knowledge centres with respect to drought warning, management options and variable technology transfer must be ensured. Available agro advisory tools such as TNAU - AAS, IMD - Meghdoot to be popularised among the farmers to reduce weather-based risks.

\section{CONCLUSION}

Drought is a recurring phenomenon and its frequency is likely to increase with the future predicted climate change in Tamil Nadu.The dryland areas of Tamil Nadu will be affected severely if proper drought coping measures are not prepared. It is all about how well the government, scientific community and farmers are actively engaged together to address the seriousness of this issue in orderto reduce vulnerability of droughts. While re-organizing the agroecological zones based on the current and future drought scenarios, crop management systems, inputs and training needed for their implementation, policy and institutions to support them and investments from public and private sources to fund the various planned measures should be planned simultaneously.Timely information to farmers, early warning systems, use of innovative modern ICT tools in drought monitoring and management should be planned at 
different levels. Though good policies are important, it is all the more necessary that they should be supportive and easy to implement to address the risks from droughts that are not going to be easy to address if we do not change the way we are working now.

\section{ACKNOWLEDGEMENT}

Authors are thankful to"The CCP-SPLICE division of Department of Science and Technology, Government of India, New Delhi" for their financial support in taking up this study through the BRIFS scheme. The technical contribution of the stakeholders in developing this paper is greatly acknowledged.

\section{REFERENCES}

Chetan Chauhan (2017). Extreme weather in India taking a toll on people and economy in India Times Web page, 20.9.2017

CSO (2019). Press note on first advance estimates of national income 2018-19, CSO, Ministry of Statistics and Programme Implementation, GOI, New Delhi.

Directorate of Economics and Statistics (2003). Agricultural Statistics at a Glance, Directorate of Economics \& Statistics, Dept. of Agriculture \& Cooperation, Govt. of Tamil Nadu.

Department of Agriculture. (2006). Department Publications, Available Online at [https://www.agriculture.gov.ie/ publications/2006/].

Economic Survey (2017). Available Online at [http:// indiabudget.nic.in/es2016-17/echapter.pdf].

ENVIS (2020). ENVIS Centre of Tamil Nadu. State of Environment and Related Issues. http://tnenvis.nic.in/ Database/TN-ENVIS_791.aspx

Geethalakshmi, V., Gowtham, R., Vengateswari, M., Bhuvaneswari, K., Panneerselvam, S. and Dheebakaran.
Ga. (2017). Impact of ENSO induced rainfall variability on maize production over Tamil Nadu. J.Agrometeorol., (Special Issue): 6-10.

Government of India. (2006). Department of Land Resources, Ministry of Rural Development, Government of India, New Delhi. http://dolr.nic.in/HariyaliGuidelines.htm. Cited 18 October 2006.

Hayes, M.J., Svoboda, M., Le Comte, D., Redmond, K.T. and Pasteris. P. (2003). Drought monitoring: new tools for the $21^{\text {st }}$ century. In: Donald A. Wilhite (ed), Drought and Water Crises, Taylor and Francis Group, Athens, 93135.

McKee, T.B., Doesken, N.J. and Kleist. J. (1993). Drought monitoring with multiple time scales. Preprints, 9th Conference on Applied Climatology, 15-20 January, Dallas, TX, pp. 233-236.

Morid, S., Smakhtin, V. and Moghaddasi. M. (2006). Comparison of seven meteorological indices for drought monitoring in Iran. Int. J. Climatol, 26(7): 971-985.

Nathan, K.K. (2001). Droughts in Tamil Nadu: AQualitative and Quantitative Appraisal.Drought Network News, 10(3): $1-6$.

NRAA(National RainfedArea Authority). (2012). Prioritization of Rainfed areas in India: Historical perspective. Prioritization of Rainfed areas in India, Study Report 4. Government of India.p.3.

Singh, H.P., Sharma, K.D., Reddy, G.S. and Sharma, K.L. (2004). Dryland agriculture in India. In: Challenges and strategies for dryland agriculture. CSSA Special Publication no. 32. Madison, USA pp. 67-92.

Tadesse, T., Wilhite, D. A., Harms, S. K., Hayes, M. J. and Goddard, S. (2004). Drought monitoring using data mining techniques: A case study for Nebraska, USA. Natural Hazards, 33(1): 137-159. 